\title{
Research
}

\section{Conceptual Models for Ecosystem Management through the Participation of Local Social Actors: the Río Cruces Wetland Conflict}

\author{
$\underline{\text { Luisa E. Delgado }}^{1}$, Víctor H. Marín ${ }^{1}$, Pamela L. Bachmann ${ }^{1}$, and Marcela Torres-Gomez ${ }^{1}$
}

\begin{abstract}
In 2004, the emigration and death of black-necked swans (Cygnus melancoryphus) from the Río Cruces wetland (Valdivia, Chile) triggered one of the largest ecosocial conflicts in Chilean history. The main local social actors of this still unsolved conflict are the Chilean government, a pulp-mill company, and a local nongovernmental organization. The central issues of the conflict are disagreement over the reason for the swans' migration, the need to restore the black-necked swan population in the wetland, and the relationship between economic development and wetland conservation. We applied a physical, ecological, and social system approach to generate conceptual or qualitative ecosystem models representing the perceptions of all social actors. Our results showed that each actor group perceived the ecosystem in a different and, in some cases, divergent way. Furthermore, all of them carried only partial representations of the wetland and the conflict. We linked all the models to generate an integrated view of the Río Cruces wetland ecosystem. We propose that this approach can be replicated as a tool for generating synthetic, integrated conceptual models of ecosystems, even in the presence of strong divergence and a lack of consensus among social actors.
\end{abstract}

Key Words: Cygnus melancoryphus; black-necked swans; conceptual ecosystem models; conflict; social actors; wetlands

\section{INTRODUCTION}

As observed by Redman et al. (2004), "the isolated study of ecological and social systems is no longer defensible." Human societies have modified most, if not all, of the ecological systems on the planet. This is affecting humans and human development in ways only anticipated by the pioneer book Limits to Growth (Meadows et al. 2004). Because we can describe the natural world at present as an interactive set of social-ecological systems, it is essential to consider human societies as reflexive components of the ecological systems upon which we depend.

This condition requires a change in the current dominant scientific epistemology. Such a change is necessary because "normal science" (sensu Kuhn 1962) does not incorporate social perception. "Postnormal science" is an interesting and challenging emerging epistemology that incorporates both scientific knowledge and social perception as requirements for understanding an intersubjective reality. Postnormal constructivism proposes that knowledge cannot be understood as the image of an ontologically objective reality, but rather as the organization of worlds generated in our experience (von Glasersfeld 1984, Jones 2002, Delgado and Marín 2005, Marín et al. 2008). Thus, different social actors, including scientists, will perceive different ecosystem components and interactions depending on the mental model used in the perception process (Kolkman et al. 2005). These different and sometimes divergent perceptions must be acknowledged and eventually incorporated into ecosystem management and conservation programs. Conceptual or qualitative ecosystem models generated by social actors, i.e., participatory modeling, represent a promising strategy for making those perceptions available to decision makers.

In South America at the current time, relevant definitions, delimitations, analysis, and strategies in the field of environmental issues are normally generated by groups of experts based on their 
investigations, publications in scientific journals, and previous work on the topic. The social context in which ecological problems are analyzed is seldom considered, let alone the way in which such problems are perceived by local actors. However, despite this technocratic dominance, important changes are taking place in the way ecological problems and integrated management are perceived and analyzed. This has been facilitated by the development of holistic, transdisciplinary, and participatory visions of science (Berkes and Folke 2000, Costanza and Jorgensen 2002, Kangas and Store 2003, Marín and Delgado 2007, Marín et al. 2008).

The conceptualization and methodology behind the physical-ecological-social system (PHES system) approach is one strategy that we have developed and applied as a tool that enables scientists and other social actors to communicate with one another on the subject of integrated management. It relies heavily on participatory modeling.

Below we describe the PHES system methodology and its application to one of the most controversial environmental conflicts in Chilean history. This conflict was initiated by the sudden emigration and death of black-necked swans (Cygnus melancoryphus) from the Río Cruces wetland in 2004.

\section{SITUATIONAL ANALYSIS}

\section{Origin and ecology of the Río Cruces wetland}

The Río Cruces wetland, located in Valdivia, Chile (Fig. 1), had its origins in May 1960 in one of the world's strongest recorded earthquakes, which measured 9.6 on the Richter scale. This earthquake caused the subsidence and consequent flooding of the agricultural lands surrounding the Cruces River and generated a 4877-ha wetland (Muñoz-Pedreros 2003). The wetland is located in an agriculturally dominated watershed in which forestry has become one of the main economic activities. Its landscape is characterized by the location of agriculture and cities on low-slope areas around rivers and wetlands. Native and exotic forests are located in higher-slope terrains. The watershed is a highly modified zone that is affected by several industrial outfalls (Guarda 2001, Contreras 2006, Otero 2006).
The wetland became a Ramsar Convention (http:// www.ramsar.org/) site in 1981, with the goal of contributing to the protection and conservation of bird species that are endangered, e.g., Coscoroba coscoroba and Plegadis chihi, or vulnerable, e.g., Pandion haliaetus, Ardea cocoi, and Cygnus melancoryphus. The wetland also became a nature sanctuary under Chilean law on 3 June 1981 based on its high bird density and diversity (Schlatter 1998). The black-necked swan is the wetland's most emblematic bird, emerging as a social symbol of the wetland that represents quality of life. The blacknecked swan has shown sudden changes in abundance since the first available records in the 1980 s. However, its population was generally stable $(5180 \pm 1200)$ for $7 \mathrm{yr}$, from 1998 through mid-2004 (Fig. 2). The swan's diet used to consist primarily of an invasive macrophyte, Egeria densa, which formerly covered nearly $60 \%$ of the floodplains of the wetland with a total biomass of 3000 metric tonnes (Ramirez et al. 2006, Boettcher 2007).

\section{A sudden regime shift: the events of 2004}

In February 2004, a pulp mill began operations, discharging its industrial effluents into the Cruces River some $25 \mathrm{~km}$ upstream from the wetland. The building of the pulp mill was authorized by the Chilean government in 1998 after the approval of an environmental impact assessment study and in the face of considerable public debate (Government of Chile 1998). On the one hand, there was strong support for building the mill, because it would provide substantial employment in the area. On the other, citizens expressed their concern about the lack of integrated watershed management plans and the potential effects of large-scale forestry.

In May 2004, the macrophyte Egeria densa suddenly disappeared from the floodplain (Ramirez et al. 2006, Lopetegui et al. 2007, Marín and Delgado 2008b, Marín et al. 2009). Water that had been transparent in the presence of the macrophyte became turbid. Subsequently, the black-necked swan migrated from the wetland to other locations either outside of the watershed or within the same area but outside the Río Cruces wetland (Jaramillo 2005, Marín and Delgado 2007). The black-necked swan reached its lowest population abundance in February 2005, with only 289 individuals in the wetland (Fig. 2). Although several hypotheses were proposed and several studies were conducted (e.g., 
Figure 1. Geographic location of the Río Cruces wetland.

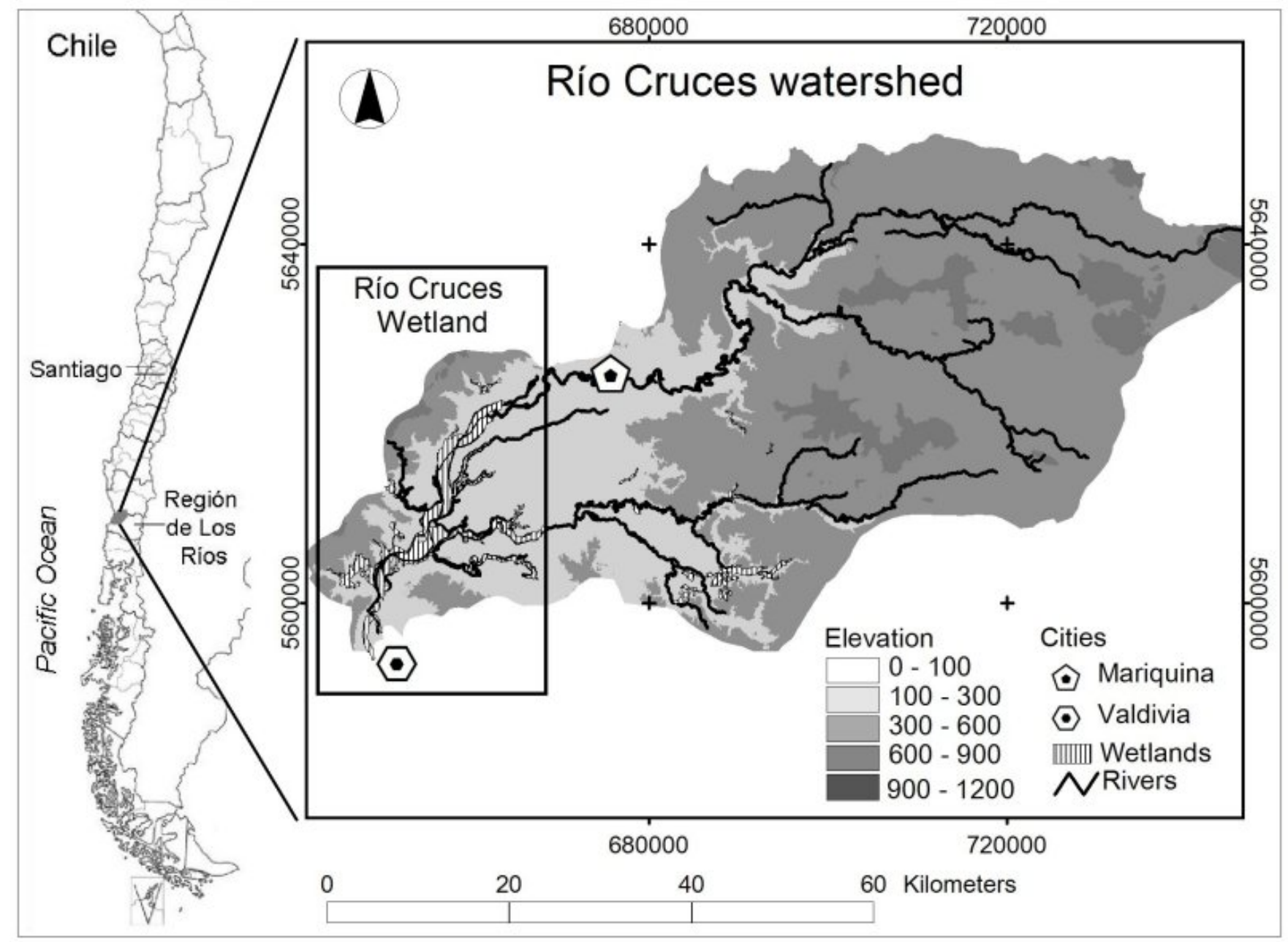

Ramirez et al. 2006, Lopetegui et al. 2007, Marín and Delgado 2008b, Palma et al. 2008), a study contracted by the Chilean National Environmental Commission (CONAMA 2005) to a local university resulted in a report (Jaramillo 2005) proposing that these changes were the result of the pulp mill's operations. These results were quickly accepted by both the local residents and the government.

An opinion-perception population survey conducted in March 2008 in the communities surrounding the wetland (LME 2008) showed that $93 \%$ of individuals perceived that the wetland had suffered clearly visible, significant changes, e.g., turbid water flows. The main identified losses were noted as being related to changes in flora and fauna (83\%) and quality of life (45\%). The survey further showed that the local population perceived changes in several ecosystem services, including tourism $(67 \%)$, fishing $(41 \%)$, water consumption for animals (33\%), and recreation $(26 \%)$. 
Figure 2. Time variability of black-necked swans (Cygnus melancoryphus) in the Río Cruces wetland. Source: http://www.conaf.cl.

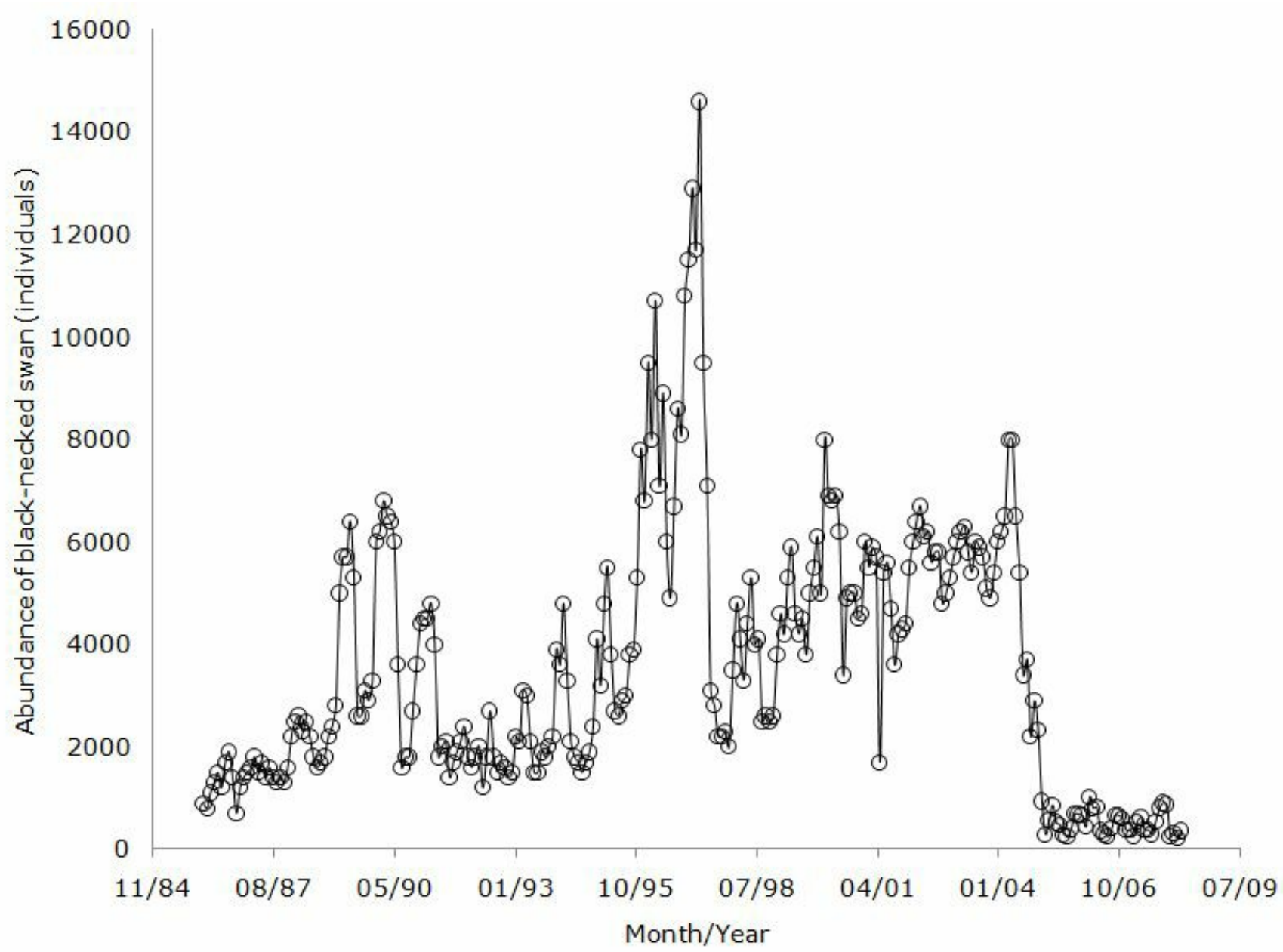

\section{The environmental conflict}

A conflict is a state of discord caused by the actual or perceived opposition of needs, values, and interests. An environmental conflict involving elements of nature and society may occur when a sudden ecological change, e.g., a shift from a clear water to a turbid water regime, generates divergent perceptions about the cause, which social actors such as industry, governments, and local actors may attribute to different factors, e.g., natural phenomena, industrial discharges, or poor watershed management. In the case of the Río Cruces regime shift in 2004, the basis of the conflict was the migration of black-necked swans from the wetland, or their death, which resulted from the disappearance of the macrophyte Egeria densa. The main social actors involved in this conflict, up to the time this article was being written, were the Chilean government (CONAMA), the pulp-mill company (CELCO), and a local NGO called Acción por los Cisnes (http://www.accionporloscisnes.org ). The Chilean government and the local NGO blamed the pulp-mill company for the changes in the wetland (based on the Jaramillo 2005 study). The industry countered that the changes were not related to the discharge of their industrial effluents (based on, for example, Ramirez et al. 2006, Marín and Delgado 2008b, Palma et al. 2008). 
The conflict remains unresolved even though the Chilean government has initiated several actions, including a lawsuit (http://www.lanacion.cl/prontus noticias/site/artic/20050428/pags/20050428210633. html) filed on 25 April 2005, a Río Cruces wetland integrated management plan (http://www.conama.cl/ portal/1301/article-36365.html), and the inclusion of the wetland in the Montreaux Record of Ramsar sites. Outstanding issues include: (1) the explanation for the swans' decline, e.g., whether it was a natural event or one related to industrial activity; (2) the need to restore the black-necked swan to its original population density through ecosystem management, although it is questioned whether or not this can actually be done, and whether or not the Chilean government should dedicate the necessary resources to it; and (3) whether industrial development should occur in areas considered to be nature sanctuaries. This conflict can be explained, from the point of view of postnormal epistemology (Funtowicz and Ravetz 2000, Marín and Delgado 2008b, Marín et al. 2008), on the grounds that the stakes are so high that solutions based on compromise are almost impossible. It is within this complex conflict that we have applied the PHES system methodology. The main goal was to generate a conceptual model that would synthesize the relationships among the ecological, social, and economic components that structure the ecosystem. We decided to use this approach because of the degree of conflict, which prevented joint, consensus-seeking meetings, and the low level of knowledge among the actors about their perspectives. We proposed that the presentation of conceptual models generated by the different social actors could be used as a basis for further communication and could aid in the implementation of the integrated management plan for the Río Cruces wetland ecosystem.

\section{METHODOLOGY}

\section{A comparison of participatory modeling approaches}

There are several methods available to facilitate the participation of social actors in decision making. Most of them support the debate of ideas about a given project or management program, with the goal of reaching consensus about future management options. The most frequently used methods are focus groups, citizens' juries and consensus conferences, participatory planning, scenario workshops, and participatory modeling (Hare et al. 2003, Kallis et al. 2006). According to Hare et al. (2003), social actors participating in ecosystem management generally aim to:

- empower the participants,

- improve democracy in decision making,

- increase the legitimacy of management decisions,

- increase project effectiveness,

- improve management in response to high degrees of uncertainty and risk, and

- include local knowledge in decision making.

One of the main criticisms of the methodologies that do not include participatory modeling is that they do not contribute to social learning. Although they make it possible to gather a wide spectrum of social knowledge and opinions, the basic dynamics are bottom up. Social actors provide only basic information for decision makers. The building of models is left to experts alone (Hare et al. 2003).

Participatory modeling, on the other hand, encourages social learning about the ecological system using systems diagrams as the main tool. The primary strengths of these diagrams are that they:

- facilitate an understanding of the dynamics and complexity of social-ecological systems,

- allow a graphical visualization of the potential effects of human actions within a system,

- encourage reflection on the role of humans within social-ecological systems, and

- facilitate the identification of the use of ecosystem services by social actors and highlight differences in values.

The two most common methods of participatory modeling are group model building (Vennix 1999, Stave 2002, Videira et al. 2003, 2005) and mediated modeling (van den Belt 2004, Kallis et al. 2006). These methods, based on systems dynamics and ecological economics, have contributed to the 
management of complex environmental problems through the collaboration and search for consensus among social actors.

\section{The physical-ecological-social system approach}

The main difference between the PHES system approach and other participatory modeling methodologies is that consensus among social actors is not required. A detailed comparison of the different participatory modeling approaches is shown in Table 1. Because of the advantage of not requiring consensus, we proposed that a socialecological analysis of the Río Cruces wetland conflict, particularly as it relates to integrated management of the wetland, should be carried out on the basis of the PHES system concept (Delgado and Marín 2005, Delgado et al. 2008, Marín et al. 2008, Marín and Delgado 2008a). The concept is based on a postnormal constructivist epistemology and on system dynamics and complex concepts inherent in social systems concepts.

A PHES system is an observer-dependent, spatially explicit, conceptual model of an ecological system whose components and boundaries depend on the questions being addressed, the observers who formulate them, and the social context in which they were proposed. A PHES system is, therefore, a socially dependent model of the society-nature relationships that arise as part of an integrated approach to the management of a given region of our planet. Most methodological details of the PHES system approach have been discussed in Marín et al. (2008).

The concept incorporates two new characteristics in relation to previous ecological system concepts. First, human societies are explicitly incorporated as reflexive system components, an issue widely discussed by Berkes and Folke (2000). Second, the bioecological components considered, e.g., other species in the defined area, are only those necessary for dealing with the proposed question. This does not mean considering species that are only of interest to humans; there is extensive literature showing that indirect interactions are critical to ecosystem functioning. What it does mean is that it is not necessary to incorporate "all organisms" (sensu Likens 1992) as a requirement for ecosystem management. This concept is explained schematically in Fig. 3.
A PHES system is defined through a series of meetings during which the social actors in a given ecological system share their visions and the effect of those visions on the eco-social structure of the system. To be effective, this participatory process should improve the mutual understanding of all the actors' perspectives. If the process were left to academics, we would run the risk of emerging with a single model that would tend to carry the perceptions of the dominant scientist (sensu Bordieu 2003).

The generation of PHES systems for a given ecological system and, in the extreme case, for every social actor group will produce one of two results. Either all models will easily converge, generating agreement among all actors, or models will be divergent or reveal partial perceptions showing the "perspective effect" (Waltner-Toews et al. 2003, Delgado et al. 2008). In the latter case, the group of scientists is left with the job of attempting to link all these models; alternatively, they may decide that the stakes are so high that visions cannot be merged, in which case all of them have to be described, synthesized, and passed on to decision makers. This latter scenario will be described in the work that follows.

Although there are several ways to generate conceptual or qualitative ecosystem models, we have proposed methods that should maximize the likelihood of obtaining the different visions available from social actors. The method we have applied corresponds to a two-step sequence. The first step is a brainstorming session, followed by participatory modeling using commercially available languages for programming graphical simulations. This method is based on the idea that a brainstorming session generates an environment in which people can express their points of view in an open manner (Marín et al. 2008). It uses icons as the most accessible form of symbolic understanding (Hannon and Ruth 1997, Vennix 1999, Hare et al. 2003).

The participatory modeling that follows the brainstorming is generated by means of graphical systems simulation programming languages such as STELLA Research, Vensim PLE, or Powersim Studio 7. In our case, we decided, as have other authors, e.g., Costanza and Ruth (1998) and van den Belt (2004), to use STELLA Research. The STELLA Research 9.1 graphical simulation system (isee systems, Lebanon, New Hampshire, USA) has 
Table 1. Comparison of participatory modeling approaches. PHES stands for "physical-ecological-social," and STELLA is the STELLA Research programming language.

\begin{tabular}{llll}
\hline \hline Modeling approach & Group model building & Mediated modeling & $\begin{array}{l}\text { Conceptual PHES system } \\
\text { modeling }\end{array}$ \\
\hline
\end{tabular}

References

Objective /modeling focus

Social actors

Total number of participants

Composition of the modeling team

Modeling tools

Session's design

Session duration

Model sectors

Advantages

Disadvantages

Evaluation/validation

Final product
Vennix (1999)

Stave (2002)

Videira et al. (2003)

To provide a neutral conceptual framework for discussion and a platform for consensus

Regional organizations, local Members of public and associations, local managers, private organizations, research institutions citizens

Kallis et al. (2006) among participants
Marín et al. (2008)

Interactive construction of models to understand the system dynamics, with the goal of obtaining a model derived from consensus

40 people (average workshop Small (5-12) or big (50-100) size) groups

One facilitator, one modeler, One mediated modeler three process coaches/ recorders, one gatekeeper

Qualitative causal diagrams and quantitative dynamic models

STELLA-based quantitative modeling

Participatory generation of qualitative ecosystem models to discuss ecosystem management, based on a postnormal-constructivist approach in which consensus is not required

Social actors' groups previously identified and classified (DFID 2002, Bryson 2004)

12-15 people/modeling session, 1 session/group

One brainstorming coordinator, two or three facilitators to guide the modeling session

STELLA-based qualitative modeling

It is based on three sessions: One session divided into two qualitative model building, steps: brainstorming and Large group meetings and small group modeling meetings; the modeling team develops the technical work before the sessions quantitative model building, qualitative model building and simulations.

Seven sessions with a total of At least 3 days nearly $50 \mathrm{~h}$

Sectors not defined as a priority

Sectors not defined as a priority

Large number of participants; generation of a consensus model

Large number of participants: generation of a consensus model

Workshop duration; consensus is required

Semi-structured interviews before and after the workshop

The overwhelming role of the mediated modeler; consensus is required

Semi-structured interviews before and after the workshop

Model, reports, database

Unique numerical model
3-4 h with a 30-min break between steps

PHES system sectors (physical, ecological, social)

Generation of conceptual models in one session per group; consensus not required

The low number of participants in each session

Done by the actors at the end of the modeling session or by correspondence afterward

One or more PHES system models 
Figure 3. Relationships between the "contemporaneous ecosystem concept" (Likens 1992), human societies, and the physical structure of the system within the physical-ecological-social (PHES) system. All information was filtered by the observers in relation to the questions being asked and the proposed methods of and approaches to dealing with them.

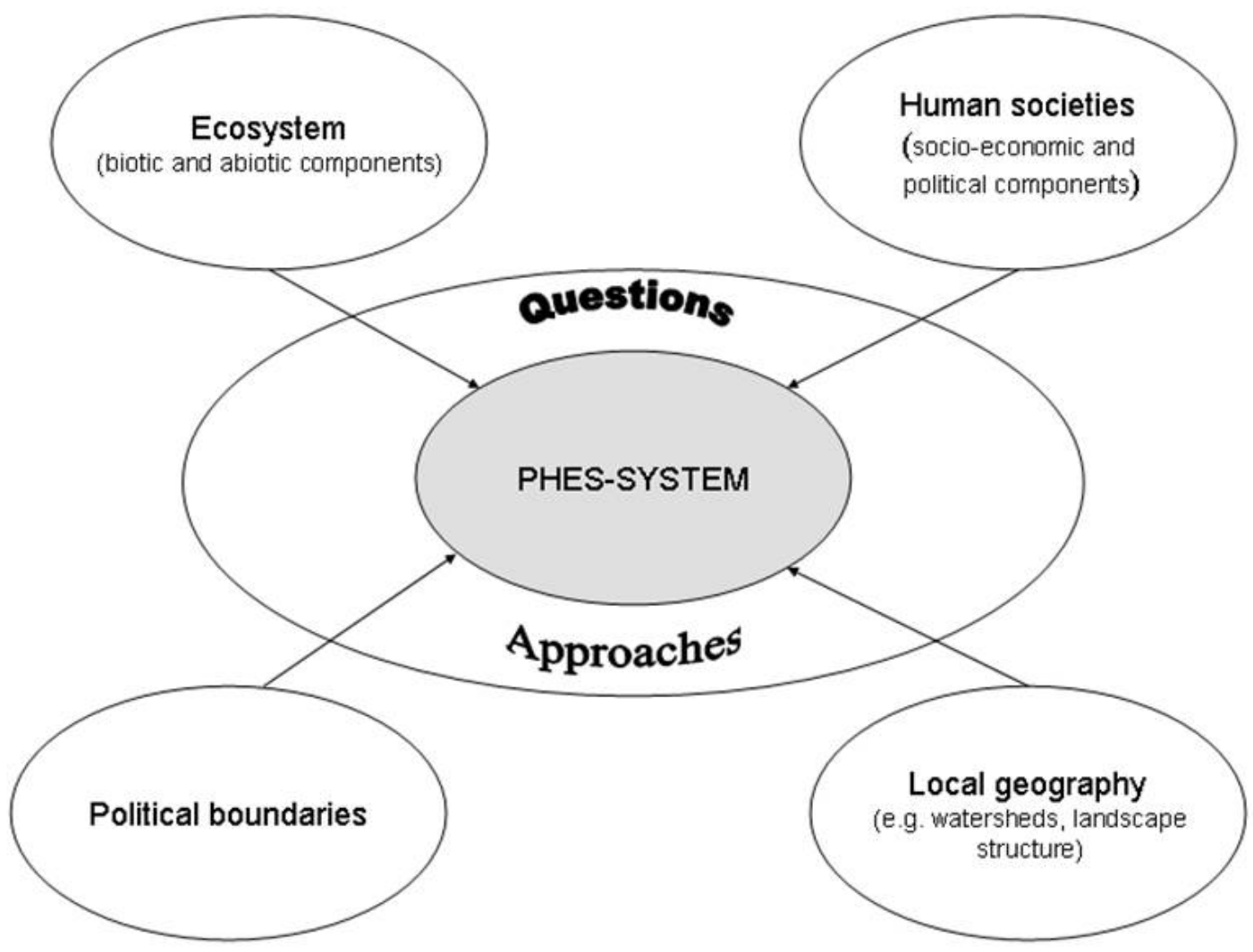

four tabbed pages: Interface, Map, Model, and Equation. Although some authors advocate the use of causal diagrams (e.g., Stave 2002), we preferred STELLA's system dynamic representation of the stock-flow structure, given its common use in ecological modeling. A strength of STELLA is the ease with which processes or flows, e.g., information, water flows, trophic dynamics, state variables, and converters, can be visually identified. Furthermore, qualitative stock-flow models have been successfully translated into quantitative models (e.g., Videira et al. 2003) and as decision support systems (van den Belt 2004). When it starts running, STELLA opens onto the Map layer. This is where participants lay out their thinking and perceptions about the social-ecological system, i.e., the conceptual, qualitative, ecosystem model or PHES system, in the form of a map, using four building blocks (see Appendix 1 for details). 
Each modeling session has one brainstorming coordinator and two or three facilitators, normally one for every five or six participants, who have a working knowledge of modeling. The coordinator's role is to ensure that the information gathered during the first part of the session is used for model building. The steps in the PHES system approach are presented in a flow diagram in Fig. 4. The PHES system methodology was originally proposed (Delgado and Marín 2005), tested, and used (Marín et al. 2008) in situations in which different social actors could jointly participate in a single modeling session. However, conflict in the Río Cruces situation was high enough to prevent joint consensus-building meetings. Therefore, we changed the method and generated a session for each of the social-actor groups that we could recognize. This change implied analyzing and categorizing social actors to generate groups that shared similar perceptions of the conflict at a preliminary stage (Marín and Delgado 2007). We identified five groups of social actors using the concepts and strategies proposed by the UK Department for International Development (DFID 2002); these groups included macro-enterprises, micro-enterprises, governments, NGOs, and the local academy. Questions for the brainstorming sessions were divided into three groups. There were common questions with the goal of comparing perceptions among all social actors, questions for specific sectors oriented toward comparing pairs of groups, and specific questions targeted to particular groups for the purpose of gathering basic information from specific social actors.

The common questions intended to compare perceptions were:

- What does the wetland represent for your institution?

- What do you understand by "restoration" in terms of benefits and responsibilities?

- What does the wetland conflict mean to you?

The sector-related questions were:

- For government and NGOs: What are the main ecosystem components and services?

- For government and corporations: How important is the return of swans?
- For academics and NGOs: What are the main consequences of the ecosystem change?

The specific questions to elicit basic information were:

- For government: What are the main contaminants?

- For corporations: What has your institution done in support of the wetland?

- For academics: What do you know about the event that triggered the ecosystem change in 2004 ?

Invitations for each of the five brainstorming sessions were sent a month in advance to 86 people or organizations. The invitation included the set of questions that would drive the sessions. Table 2 shows the participation statistics for each category of social actor. The lowest participation was found among micro-enterprises (17\%) and NGOs (21\%). In the case of micro-enterprises, one participant claimed that he was actually representing several (> 50) organizations. In the case of the NGOs, many of them cited a lack of confidence in the government with regard to the management of the Río Cruces conflict as grounds for refusing to participate. Comments about this appeared in a local newspaper (Valdivia Noticias 2007).

All sessions ended with the generation of a conceptual or qualitative model. The models and the transcripts from the brainstorming sessions were sent to the participants, who were given a month to submit their comments. Transcripts were analyzed via a content analysis methodology using the software ATLAS.ti (ATLAS.ti Scientific Software Development GmbH., Cologne, Germany; Bachmann et al. 2007a). A report was made available online that included our analysis and a synthesis of all the models and sessions (Marín and Delgado 2008b). The report was open to online feedback for another month and was advertised in the online newspaper Valdivia Noticias for a two-month period. The final integrated model, FIM, can be viewed in Appendix 1. All five individual models in STELLA are available from the authors.

The structure of the FIM was analyzed in terms of its complexity, i.e., the number of components and connections and the dependency of its subsystems. 
Figure 4. Sequential steps for the generation of conceptual physical-ecological-social (PHES) system models.

Send key questions to participants, one or two weeks prior to the session

\section{Develop brainstorming session}

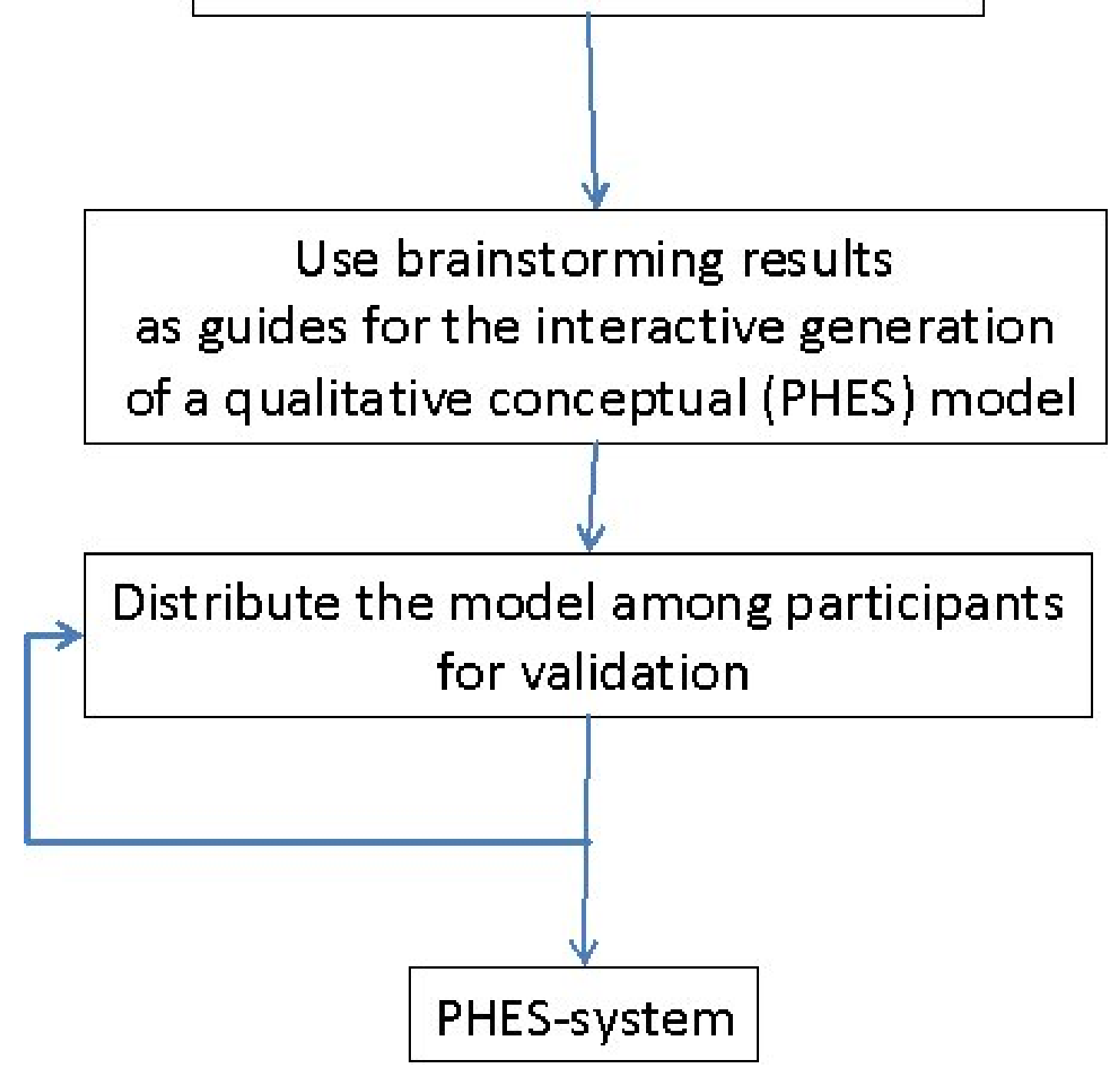


Table 2. Participation statistics for the Río Cruces brainstorming/modeling sessions. Numbers in all categories correspond to organizations, with the exception of "local academics," which corresponds to researchers

\begin{tabular}{lccc}
\hline \hline Social actors' groups & Invitations & Participants & Participation (\%) \\
\hline Macro-enterprises & 25 & 12 & 48 \\
Micro-enterprises & 18 & 3 & 17 \\
Government & 8 & 4 & 50 \\
Local academics & 8 & 4 & 50 \\
NGOs & 14 & 3 & 21 \\
Total & 86 & 34 & 40 \\
\hline
\end{tabular}

The latter was estimated through two ratios: (1) the ratio between foreign components belonging to a different subsystem, e.g., a wetland appearing in the economy subsystem, and those belonging to the subsystem under analysis and (2) the ratio between the number of intersubsystem and intrasubsystem connections.

\section{RESULTS}

\section{Qualitatively coding societal relationships within the Río Cruces wetland}

Figure 5 shows the results of the coding and interpretation of all five brainstorming sessions. We identified 11 codes that represented the issues raised with the greatest frequency in all sessions. The most frequently cited codes corresponded to "conflict" and "restoration," followed by "swans." This reveals that the social actors agreed on the need to restore the wetland. Restoration, for some actors, would necessarily entail bringing the swans back. Indeed, the wetland in most cases was not identified as an "ecosystem" in the sense used in ecology, but as a place or habitat inhabited by swans. Furthermore, when the wetland was defined as a "system," the associated codes were "complexity," "system dynamics," and "management difficulties." It was also revealed that the social actors shared the perception that economic development of the area necessarily modifies the wetland and that the Río Cruces conflict restricts economic development.
The modeling results demonstrated a dual perception of the wetland. On the one hand, it was accepted that the area is important as a habitat for the swans. On the other, the area was perceived as important for the ecosystem services it generates, which in turn translate into employment opportunities. Somewhere between these two perceptions, there is an awareness that restoring the wetland will require consensus among the different social actors.

\section{Model subsystems and components}

Figure 6 depicts the FIM subsystems and the main processes that link them into a single PHES system. The internal structure of each subsystem is shown in STELLA notation in Appendix 1. Social actors named a total of six subsystems, all of them contained within the PHES system concept. The six subsystems identified are "society," "economy," "state," "watershed," "biotic," and "abiotic." The latter two correspond to subsystems within the wetland. Our analysis showed important differences among actors in the way they perceived the ecosystem (Table 3). For example, the local academics do not see "society," "state," and "watershed" as subsystems. Macro-enterprises understand the wetland as being a component within the watershed but without internal structure, i.e., the biotic and abiotic subsystems identified by academics. It is worth noting that Delgado et al. (2008) conducted a study of a different aquatic 
Figure 5. Relationships among the core concepts related to the Río Cruces wetland conflict. These were generated during five brainstorming sessions. A qualitative analysis of the texts and recordings of all sessions was carried out using Atlas.ti. The numbers in parentheses correspond to the number of times the concept was referenced during the sessions.

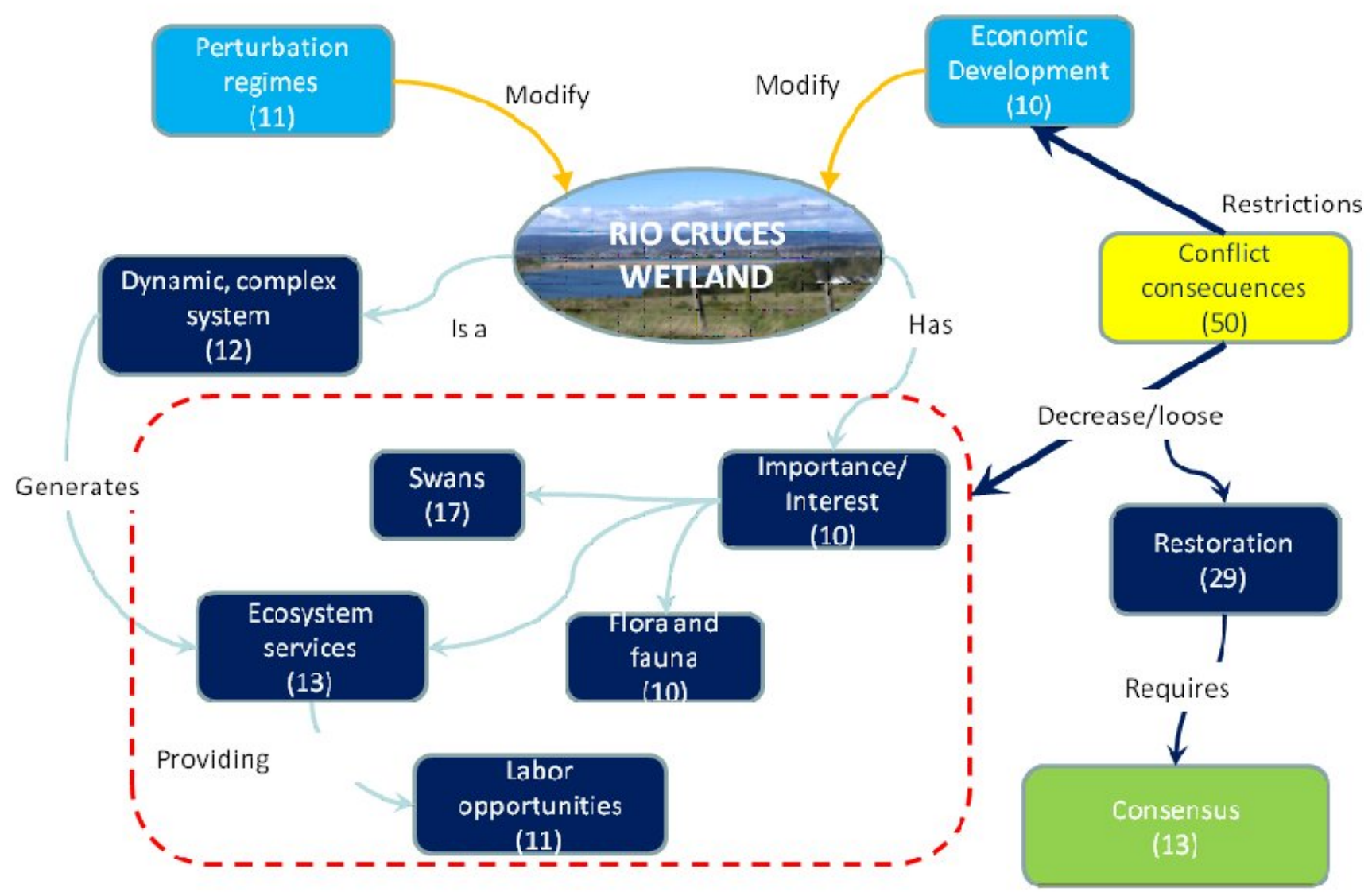

ecosystem, the Aysén Fjord in southern Chile, that produced the same result. Their comparative analysis of two PHES systems in the fjord indicated that, although the government and academic sectors recognized the biotic and abiotic structure of the fjord, the salmon farmers saw it as a single component without structure. Finally, our study found that micro-enterprises do not identify the "state" as a subsystem of the model.

The number of components and connections in the subsystems also differed between individual models
(Table 3). For example, local academics recognized seven components within the "biotic" subsystem, but NGOs and micro-enterprises recognized only two. Furthermore, not all models have the same components, which is why three of the six subsystems within the FIM have more components than the maximum found within the individual models. These differences in perception about the ecosystem, i.e., PHES systems, are even more pronounced in the case of subsystem connections. There were 30 components within the individual models, translating into 32 components in the FIM. 
Figure 6. Subsystem structure of the final integrated model. Each box corresponds to a subsystem that is identified by its name on top. The arrows represent the main process linking each subsystem to the others. The upper number corresponds to the components in each subsystem, and the parentheses show the number of components imported from other subsystems. The lower number corresponds to the interactions in each subsystem, and the number in parentheses shows the interactions imported from other subsystems.

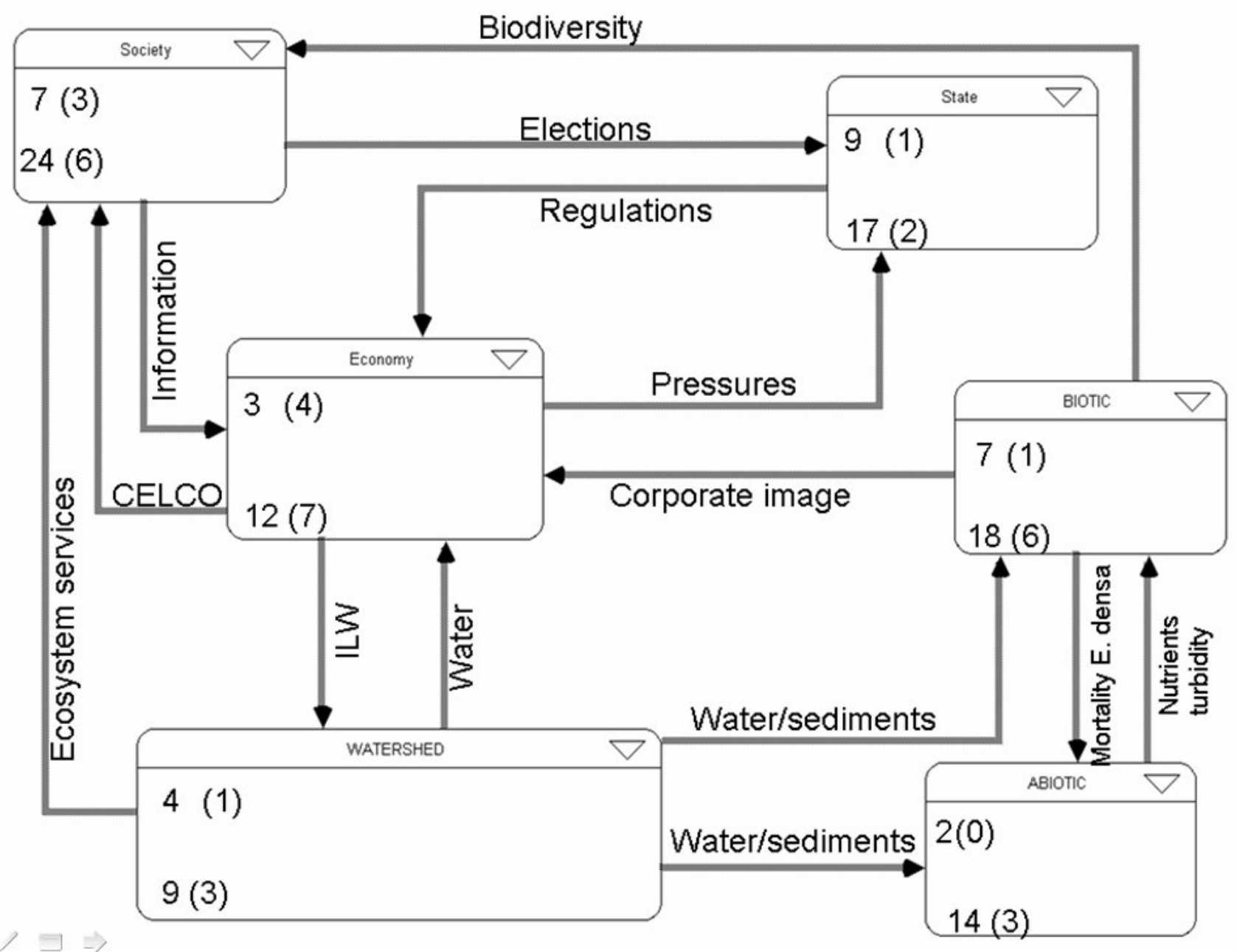

However, 30 connections within the individual models translated into 94 connections in the FIM. Many new system interactions appeared in the FIM as different perceptions were integrated. The lack of perception of many interactions within individual PHES systems is an important point to keep in mind when using synthetic modeling for integrated ecosystem management.
The "society" subsystem comprised seven components and is one of the most complex in terms of its components (Fig. 7). Five out of eight of the flows within this subsystem corresponded to information. Local scientists are perceived as important generators of information flows.

The "economy" subsystem is among the simplest in terms of both components and connections (Fig. 7). 
Table 3. Structure of social actors' models and the final integrated model (FIM) showing (A) the number of subsystem components and (B) the number of subsystem connections. "Average" refers to the average number of components and connections for individual actors' models. "MAX" refers to the maximum number of components and connections that any individual group recognized. "FIM" corresponds to the number of components and connections found in the final integrated model (see Fig. 6).

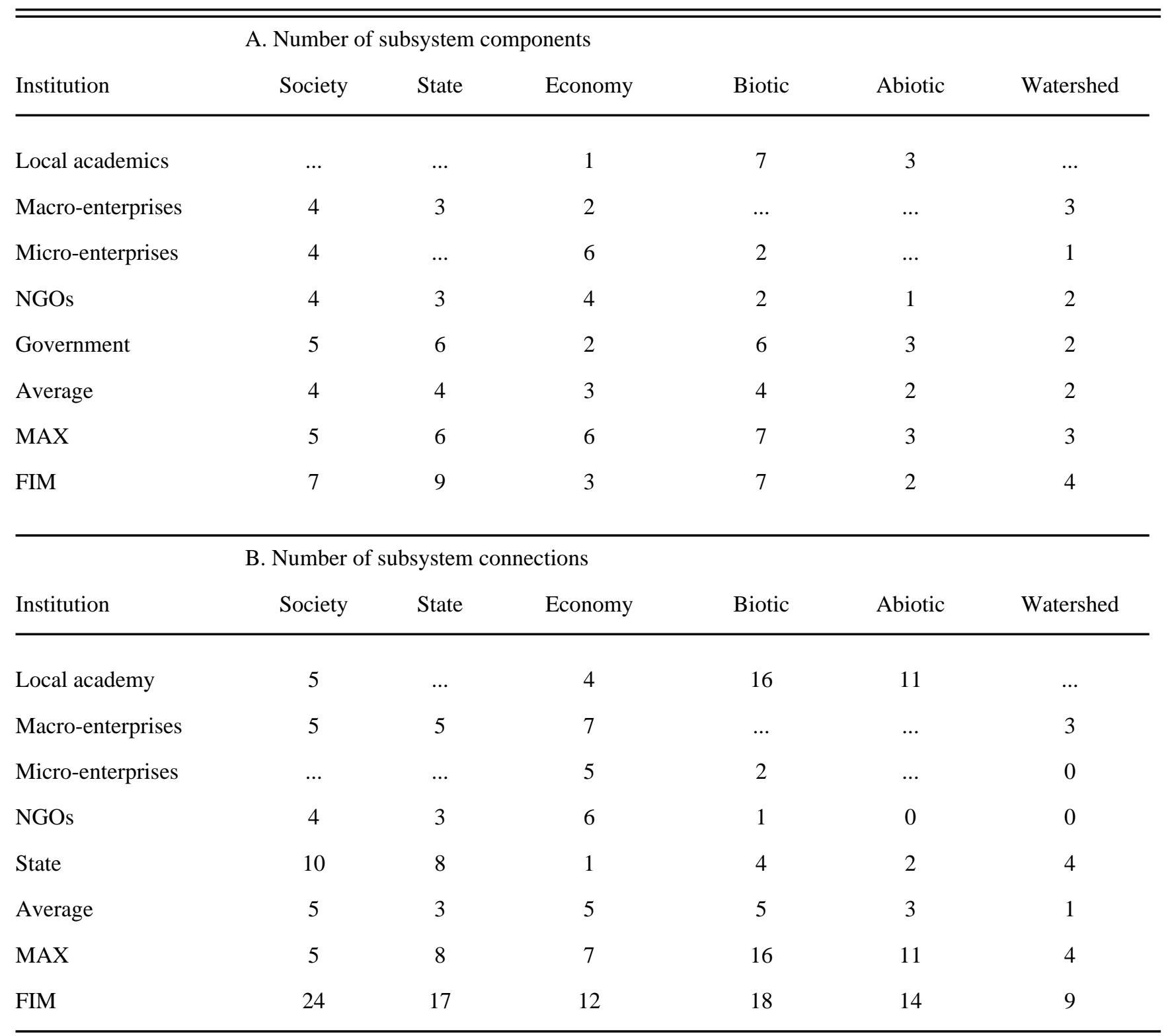


Figure 7. Complexity of the final integrated model.

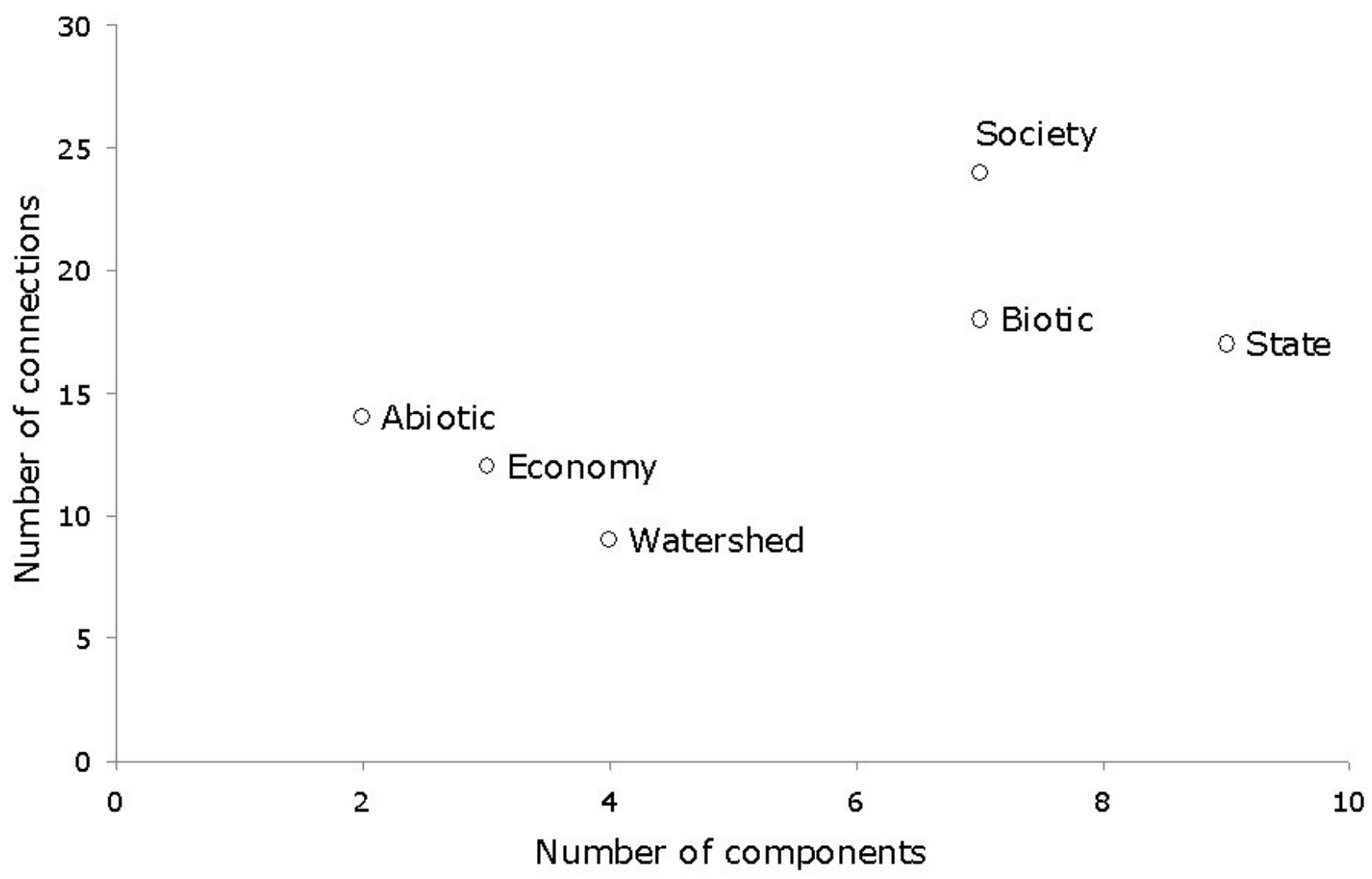

It also shows the highest dependency (Fig. 8). The pulp-mill company appears clearly as a component that is different from other industries within the system.

The "state" subsystem is also one of the most complex (Fig. 7), and, at the same time, it is the least dependent subsystem (Fig. 6). In fact, "society" interacts with it only in the form of voters during elections, and "economy" interacts with it only in terms of putting pressure on decision makers. Otherwise, this subsystem is clearly perceived to be independent. The absence of information fluxes between "society" and "state" in relation to environmental issues has also been documented in other Chilean areas (Bachmann et al. 2007a,b).
The "biotic" subsystem was primarily generated by academic and state actors (Table 3). It is one of the three most complex subsystems in the FIM (Fig. 7). Its structure follows a classical populationcommunity vision in which most trophic levels are identified. Black-necked swans and E. densa, the two main ecological elements provoking the societal conflict, are identified as separate components, although other species are considered in "black boxes," e.g., bird fauna, macrophytes. The "abiotic" subsystem was the simplest and least dependent of the identified subsystems. The mortality of $E$. densa appears as an important connector from the "biotic" subsystem, influencing the resuspension of sediments. 
Figure 8. Subsystem dependency in the final integrated model. "Com-dependency" corresponds to the dependency of components, whereas "con-dependency" corresponds to the dependency of interactions.

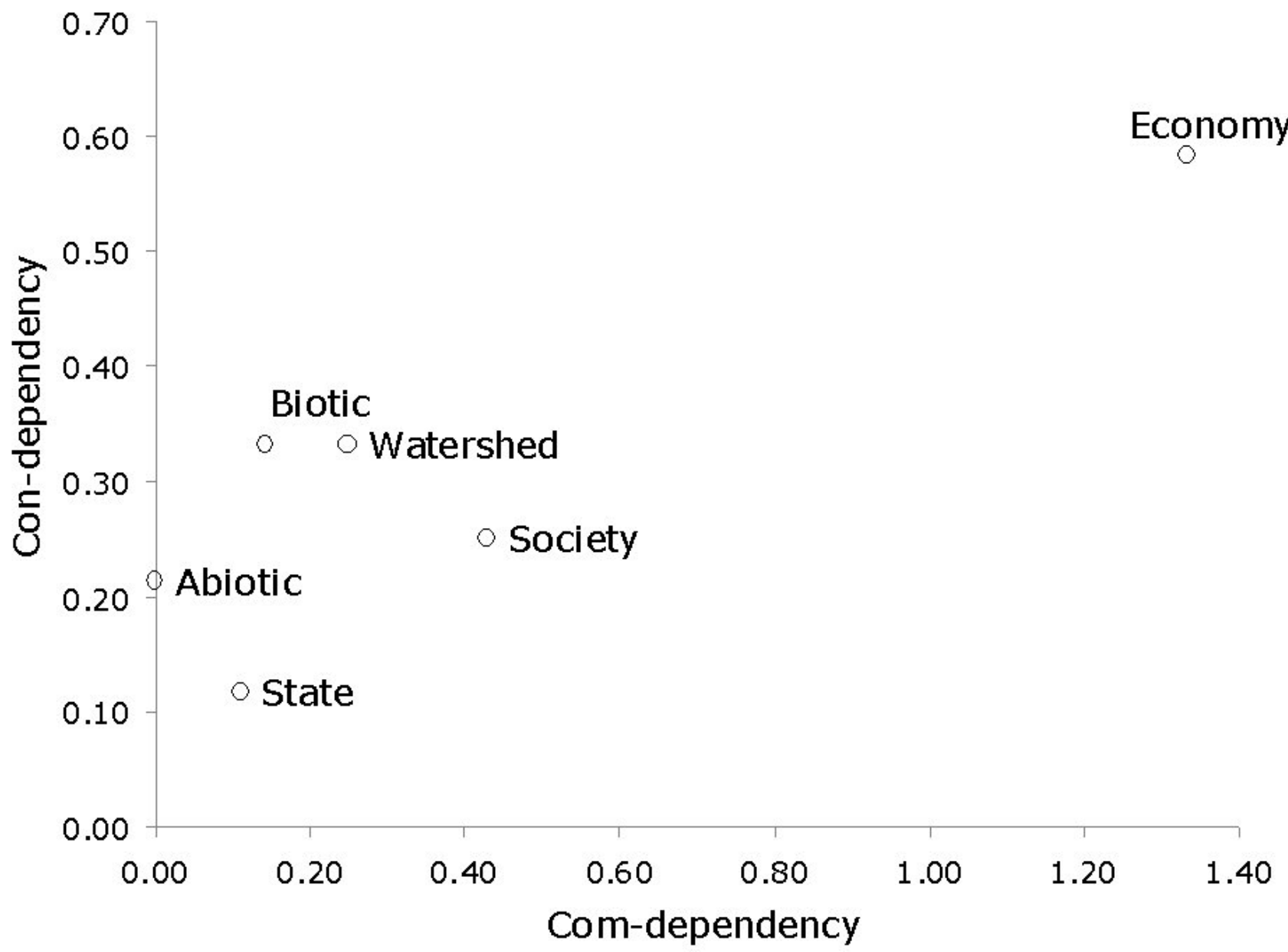

The "watershed" is an interesting subsystem because one of its components is the wetland (Appendix 1). If analyzed in strictly ecological terms, the wetland is already present in the model through the "biotic" and "abiotic" subsystems. However, as noted earlier, some actors, such as macro-enterprises, did not view the wetland as having an internal structure. It was perceived only as a sink for industrial effluents.

The main processes connecting the subsystems within the FIM also demonstrate the different perceptions that social actors have in relation to the
Río Cruces wetland (Fig. 6). For example, the connection between the "biotic" and "society" subsystems is related to biodiversity. The connection between the "biotic" and "economy" subsystems is related to corporate image. This means that, although some social actors accept the intrinsic value for black-necked swans, the decrease in population represents to a greater degree a corporate image problem for the industry. 


\section{DISCUSSION}

Nature, transfigured by human intervention, must be included as a component of our social system and a subsystem of our global culture; Giddens (1997) terms this "second nature." Nature can no longer be seen as an externality to our societies. However, we must also incorporate the idea that interactions between society and nature are perceived and understood differently by different social actors. Indeed, scientists no longer hold the only key to nature's secrets. As we have shown using a PHES system approach, the different social actors involved in the Río Cruces wetland conflict have dramatically different views about nature. For some, the problem is that every living organism has an intrinsic value, i.e., swans are a necessary part of the entire wetland ecosystem. For others, the sudden disappearance of black-necked swans is a problem only insofar as it leads to a negative corporate image.

Another interesting outcome from our brainstorming session was the complex relationship that characterized the conflict, the drive for economic development, and the health of the wetland. Both the FIM and the analysis of the brainstorming sessions showed that social actors, particularly those involved with the commercial enterprises surrounding the wetland, clearly stated that the conflict was affecting their corporate image. From their point of view, this was leading to restrictions on economic development. Other actors, e.g., tourism operators, mentioned that changes in the wetland were affecting their source of income. All actors recognized that economic development was changing the wetland. This generates a circular problem that is typical of the development model currently existing in Latin America, which is based to a large extent on the intensive use of natural resources. The nature of this problem is that economic development is considered to be "progress," which should decrease poverty by generating employment. However, such development also degrades the environment, which negatively affects possibilities for economic development. This circular way of perceiving the relationship between the economy and the environment is related to the perception of the latter as being external to societies. This concept of the invariability of nature in turn produces "environmental nostalgia" (Fig. 9).

Is there a way to put an end to this circular thinking? Our results show that social actors in the Río Cruces wetland conflict believe that achieving consensus is one of the only ways to resolve the conflict. Such consensus should entail all the social actors agreeing on a development project and its environmental consequences. However, as we have demonstrated, the actors do not know enough about, or are not in sufficient agreement with, each other's perspectives to be able to arrive at a consensus. When confronted with each other's opinions, i.e., their partial views of the system or PHES systems, the stakes are so high that no consensus is possible. The Río Cruces wetland conflict can, therefore, be categorized as a "postnormal" problem. The stakes are high, decisions are urgent, there is a plurality of legitimate perspectives, and the facts are uncertain (Funtowicz and Ravetz 2000). Under these conditions, as we witnessed during the development of our work, there is little hope of finding a solution. The only possibility is that social actors will accept their plurality, acknowledge their partial views of a complex system, and agree either to combine their views (FIM) or to analyze the effects of all different perspectives.

Our results demonstrated that local scientists may play a fundamental role in providing information. Indeed, they are perceived to be the main providers of information. At the same time, however, they are also actors in the conflict, and our analysis has shown that they too have a partial view of the system. From this perspective, scientists behave like the wise men in the elephant parable (Marín and Delgado 2008), missing several components of this social-ecological system. One example of this is the rather simple structure of the "abiotic" subsystem within the FIM. Very few actors perceived the physical-biological interactions and the abiotic components of the system. This may indeed have been responsible for an almost complete lack of physical analysis of the wetland in relation to the 2004 events (Marín et al. 2009).

Can the PHES system approach help social actors to have more than a partial view? The answer to this question is as complex as the FIM we generated (Appendix 1). The authors of this article did not reach consensus on an answer, and, as postnormal scientists, we did not force a consensus. However, our experience did demonstrate that the PHES system approach serves as a useful communication tool among social actors (Marín et al. 2008). It is when actors' perceptions represent partial views of a rather complex system that a synthesis becomes troublesome. 
Figure 9. The production of "environmental nostalgia" associated with economic development based on the intense exploitation of natural resources and environmental conditions.

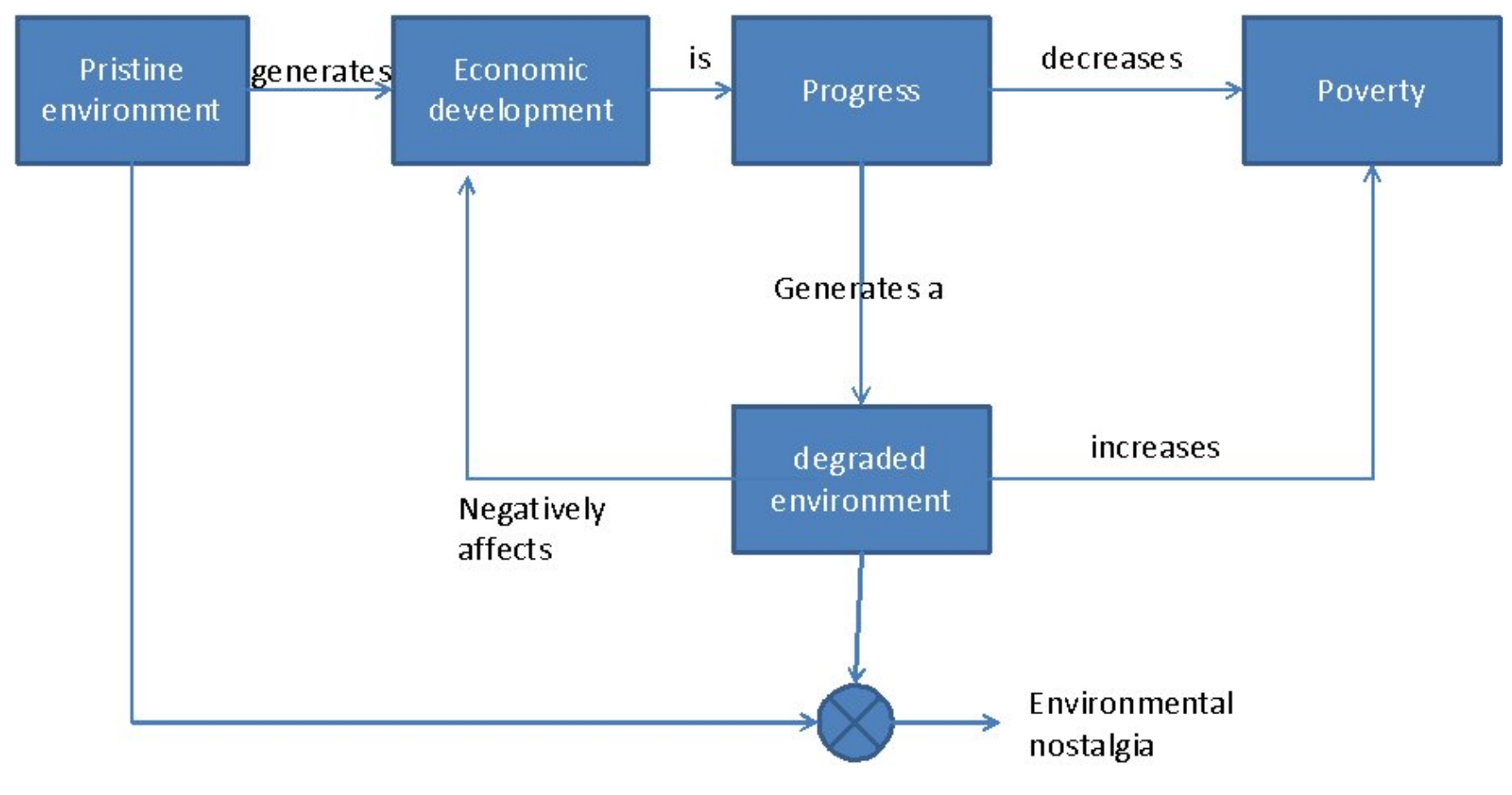

The FIM, when analyzed in terms of its components, is almost equal to the sum of all views. However, in the case of interactions, the FIM includes a substantial number of interactions that were not generated by the social actors. This is a consequence of synthesizing those views, because many connections or flows had to be built while the different pieces were being connected and could not appear beforehand. The authors' views on this differed. For some, this may represent a problem, because no actor would acknowledge the resulting model as his or her own. For others, this is the strength of the PHES system approach, because it indeed shows that it is possible to reconstruct a system starting from the opinions, visions, and perceptions of the social actors, as divergent as these might be. All the authors agreed that the PHES system approach generates a synthetic, integrated perspective of an ecosystem that can be used by decision makers. Through the FIM analysis, decision makers could indeed identify important processes, indicate variables that should be monitored, and even propose management measures to be implemented using an ecosystem approach (Marín and Delgado 1997).

Ultimately, it would not have been possible to arrive at the FIM using other participatory modeling approaches (see Table 1). However, van den Belt (2004) cautions about the limitations of mediated modeling by stating that this approach should not be used "when stakeholders are not prepared to be present in a room and to work together on a voluntary basis." Group model building (Vennix 1999, Stave 2002, Videira et al. 2003) and mediated modeling (van den Belt 2004, Kallis et al. 2006) have been developed with the premise that consensus among social actors is both required and agreed upon by all involved parties. If there is more than one legitimate perspective in the model, then the very foundation for consensus starts to weaken.

The role of science in our society, especially if this is accepted to be a postmodern society, can no longer be to generate unambiguous models of ecological systems for decision makers and resource managers. 
Scientists must acknowledge that there are, and always will be, a range of legitimate perspectives that must be recognized and incorporated. When these perspectives end in a conflict such as in the Río Cruces, incorporating all visions becomes all the more urgent, even if it does not guarantee conflict resolution. As we have seen, a final agreement or consensus about the Río Cruces wetland is still pending, and the conflict is still very much unresolved. We are confident that the PHES system approach was useful insofar as the views of social actors have been recorded and organized in a way that is accessible to all actors.

Responses to this article can be read online at: http://www.ecologyandsociety.org/voll4/iss 1/art50/ responses/

\section{Acknowledgments:}

We would like to thank A. Tironi, B. Oñate, J.C. Gómez-Leyton, and I. Serey for their participation and contributions in the brainstorming and participatory modeling sessions. This research was partly funded by the Corporación Nacional Forestal (CONAF, Chile) under contract $N^{\circ}$ 633-111-LP07 and by the Facultad de Ciencias, Universidad de Chile. VHM was also supported by the Alexander von Humboldt Foundation.

\section{LITERATURE CITED}

Bachmann, P. L., L. E. Delgado, and V. H. Marín. 2007a. Analysis of the citizen's participation concept used by local decision makers: the case of the Aysén watershed in southern Chile. International Journal of Sustainable Development 10:251-266.

Bachmann, P. L., L. E. Delgado, and V. H. Marín, editors. 2007b. Toward the integrated ecological management of coastal zones in Chile: contributions of the EcoManage project. Salesianos Impresores, Santiago, Chile.

Berkes, F., and C. Folke, editors. 2000. Linking social and ecological systems:management practices and social mechanisms for building resilience. Cambridge University Press, Cambridge, UK.
Boettcher, C. 2007. Variación comparativa de biomasa estacional en dos macrófitos de la región de Valdivia, Chile. Ciencia \& Trabajo 26:191-199.

Bordieu, P. 2003. El oficio de científico: ciencia de la ciencia y reflexividad. Editorial Anagrama, Barcelona, Spain.

Bryson, J. M. 2004. What to do when stakeholders matter: stakeholder identification and analysis techniques. Public Management Review 6:21-53.

Comisión Nacional del Medio Ambiente, Dirección Regional $X^{a}$ Región de los Lagos, Universidad Austral de Chile (CONAMA). 2005. Estudio sobre origen de mortalidades y disminución poblacional de aves acuí225ticas en Santuario de la Naturaleza Carlos Anwandter, en la Provincia de Valdivia. Convenio complementario específico $\mathrm{N}^{\mathrm{o}}$ 1210-1203/ 14 December 2004. CONAMA, Santiago, Chile.

Contreras, Y. 2006. Determinación de metales traza (Ni, Cr, Cd, Cu, Fe, Mn, Al) en totora (Scirpus californicus) y sedimento en el santuario de la naturaleza Carlos Anwandter, Río Cruces, Valdivia.

Thesis. Universidad Austral de Chile, Valdivia, Chile.

Costanza, R., and S. Jorgensen. 2002. Understanding and solving environmental problems in the 21st century: toward a new, integrated hard problem science. Elsevier, New York, New York, USA.

Costanza, R., and M. Ruth. 1998. Using dynamic modeling to scope environmental problems and build consensus. Environmental Management 22:183-195.

Delgado, L. E., and V. H. Marín 2005. FESsistema: un concepto para la incorporación de las sociedades humanas en el análisis medioambiental en Chile. Revista Ambiente y Desarrollo 21:18-22.

Delgado, L. E., V. H. Marín, A. Tironi, and P. Bachmann. 2008. Conceptual PHES system models of the Aysén fjord: the case of salmon farming. Pages 581-584 in R. Neves, J. Baretta, and M. Mateus, editors. Perspectives on integrated coastal zone management in South America. IST Press, Lisbon, Portugal.

Funtowicz, S. O., and J. R. Ravetz. 2000. La ciencia posnormal: ciencia con la gente. Icaria 
Editorial, Barcelona, Spain.

Giddens, A. 1997. Política, sociología y teoría social: reflexiones sobre el pensamiento social clásico y contemporáneo. Ediciones Paidós, Barcelona, Spain.

Government of Chile. 1998. Resolution accepting the construction of the pulp mill plant of Celulosa Arauco y Constitución at San José de la Mariquina, Chile. RES. N²79/98. [online] URL: https://www. e-seia.cl/expediente/expedientes.php?modo= $\underline{\text { ficha\&id expediente }=891034 \& \text { idExpediente }=891034}$

Guarda, G. 2001. Nueva historia de Valdivia. Editorial Univerditaria Católica de Chile, Santiago, Chile.

Hannon, B., and M. Ruth. 1997. Modeling dynamic biological systems. Springer-Verlag, New York, New York, U.S.A.

Hare, M., R. A. Letcher, and A. J. Jakeman. 2003. Participatory modelling in natural resource management: a comparison of four case studies. Integrated Assessment 4(2):62-72.

Jaramillo, E. 2005. Final report: "Study about the origin of mortalities and population reduction of waterbirds in the Nature Sanctuary Carlos Anwandter, at the Valdivia Province." Complementary Agreement Number 1210-1203/2004-12-14. National Environmental Agency (CONAMA) - Austral University of Chile. Available online at: http://www .sinia.cl/1292/articles-31665 segundoinformeCisnes. pdf.

Jones, S. 2002. Social constructionism and the environment: through the quagmire. Global Environmental Change 12:247-251.

Kallis, G., N. Videira, P. Antunes, A. G. Pereira, C. L. Spash, H. Coccossis, S. C. Quintana, L. del Moral, D. Hatzilacou, G. Logo, A. Mexa, P. Paneque, B. P. Mateos, and R. Santos. 2006. Participatory methods for water resources planning. Environment and Planning C: Government and Policy 24:215-234.

Kangas. J., and R. Store. 2003. Internet and teledemocracy in participatory planning of natural resources management. Landscape and Urban Planning 62:89-101.
Kolkman, M. J., M. Kok, and A. van der Veen. 2005. Mental model mapping as a new tool to analyse the use of information in decisionmaking in integrated water management. Physics and Chemistry of the Earth 30:317-332.

Kuhn, T. 1962. The structure of scientific revolutions. First edition. University of Chicago, Chicago, Illinois, USA.

Laboratorio de Modelación Ecológica (LME). 2008. Estudio de opinión y percepción sobre el problema del humedal de Río Cruces. Proyecto "Elaboración de un modelo conceptual del ecosistemas del humedal de Río Cruces." Facultad de Ciencias, Programa PULSO, Facultad de Ciencias Sociales, Universidad de Chile, Santiago, Chile. Available online at: http://ecosistemas.uchile. cl/cruces/documentos/modelo/files/Encuesta1.pdf

Lopetegui, E. J., R. S. Vollmann, H. C. Cifuentes, C. D. Valenzuela, N. L. Suarez, E. P. Herbach, J. U. Huepe, G. V. Jaramillo, B. P. Leischner, and R. S. Riveros. 2007. Emigration and mortality of black-necked swans (Cygnus melancoryphus) and disappearance of the macrophyte Egeria densa in a Ramsar wetland site of Southern Chile. Ambio 37:607-609.

Marín, V. H., and L. E. Delgado. 2008a. A PHES system approach to coastal zone management. Pages 61-70 in R. Neves, J. Baretta, and M. Mateus, editors. Perspectives on integrated coastal zone management in South America. IST Press, Lisbon, Portugal.

Marín, V. H., and L. E. Delgado, editors. 2007. Elaboración de un modelo conceptual del ecosistema del humedal de Río Cruces. Primer informe de avance. Facultad de Ciencias, Universidad de Chile, Santiago, Chile. Available online at: http://ecosistemas.uchile.cl/cruces/documentos/ modelo/files/Informe1.pdf.

Marín, V. H., and L. E. Delgado, editors. $2008 b$. Elaboración de un modelo conceptual del ecosistema del humedal de Río Cruces. Segundo informe de avance. Facultad de Ciencias, Universidad de Chile, Santiago, Chile. Available online at: http://ecosistemas.uchile.cl/cruces/documentos/ modelo/files/Informe2.pdf. 
Marín, V. H., L. E. Delgado, and P. Bachmann. 2008. Conceptual PHES system models of the Aysén watershed and fjord (Southern Chile): testing a brainstorming strategy. Journal of Environmental Management 88:1109-1118.

Marín, A. Tironi, L. E. Delgado, M. Contreras, F. Novoa, M. Torres-Gómez, R. Garreaud, I. Vila, and I. Serey. 2009. On the sudden disappearance of Egeria densa from a Ramsar wetland site of Southern Chile: a climatic event trigger model. Ecological Modelling 220:1752-1763.

Marín, V., and L. Delgado. 1997. Manejo ecosistémico de los recursos naturales. Ambiente y Desarrollo 13:70-76.

Meadows, D. H., J. Randers, and D. L. Meadows. 2004. Limits to growth: the 30-year update. Chelsea Green, White River Junction, Vermont, USA.

Muñoz-Pedreros, A. 2003. Guía de los humedales del Río Cruces. CEA Ediciones, Valdivia, Chile.

Otero, L. 2006. La huella del fuego: historia de los bosques nativos; poblamiento y cambios en el paisaje del sur de Chile. Pehuén Editores, Santiago, Chile.

Palma, A., M. Silva, C. Muñoz, C. Cartes, and F. Jaksic. 2008. Effect of prolonged exposition to pulp mill effluents on the invasive aquatic plant Egeria densa and other primary producers: a mesocosm approach. Environmental Toxicology and Chemistry 27:387-396.

Ramírez, C. E. Carrasco, S. Mariani and N. Palacios. 2006. La desaparición del Luchecillo (Egeria densa) del Santuario del Río Cruces (Valdivia, Chile): una hipótesis plausible. Ciencia \& Trabajo 20:79-86.

Schlatter, R. P. 1998. Ficha informativa de los humedales de Ramsar. Santuario de la naturaleza e investigación científica Carlos Andwanter del Río Cruces de Valdivia. Available online at: http://www .wetlands.org/reports/ris/6CL001.html.

Stave, K. 2002. Using dynamics to improve public participation in environmental decisions. System Dynamics Review 18(2): 139-167.

UK Department for International Development (DFID). 2002. Tools for development: a handbook for those engaged in development activity. DFID, London, UK. Available online at: http://www.dfid. gov.uk/

Vennix, J. A. M. 1999. Group model-building: tackling messy problems. System Dynamics Review 15:379-401.

Valdivia Noticias. 2007. Escasa participación en taller para recuperar el santuario refleja falta de credibilidad de la ciudadania en el gobierno. Available online at: http://www.valdivianoticias.cl/ info.asp? $\mathrm{Ob}=1 \& \mathrm{Id}=14038$. van del Belt, M. 2004. Mediated modeling; a system dynamics approach to environmental consensus building. Island Press, Washington, D.C., USA.

Videira, N., P.Antunes, R. Santos, and S. Gamito. 2003. Participatory modelling in environmental decision making: the Ria Formosa Natural Park case study. Journal of Environmental Assessment Policy and Management 5:421-447.

von Glasersfeld, E. 1984. An introduction to radical constructivism. Pages 16-38 in $\mathrm{P}$. Watzlawick, editor. The invented reality. Norton, New York, New York, USA. Available online at: http://www.univie.ac.at/constructivism/EvG/papers/070.1. pdf.

Waltner-Toews, D. J., J. Kay, C. Neudoerffer, and T. H. Gitau. 2003. Perspective changes everything: managing ecosystems from the inside out. Frontiers in Ecology and the Environment. 1:23-30. 
Appendix 1. Structure of the final integrated conceptual model of the río Cruces wetland ecosystem (FIM). 